\title{
CONTROL OF LANDFILL GASES EMISSION WITH PARTICULAR EMPHASIS ON BTEX
}

\author{
DEGRADACJA GAZÓW SKŁADOWISKOWYCH \\ ZE SZCZEGÓLNYM UWZGLĘDNIENIEM BTEX
}

\begin{abstract}
Landfilling is the most popular way for waste disposal and has been widely applied globally. A large quantity of volatile organic compounds (VOCs) is released from landfills. Among them, BTEX (benzene, toluene ethylbenzene and xylene) is a major group of pollutants, which have now become a cause for concern worldwide because of their toxic properties. For this reason, strict regulations have come into force which induce researchers to find methods to reduce their emissions. This article contains descriptions of several aerobic metabolic pathways for the degradation of BTEX, which are provided by two enzymatic systems (dioxygenases and monooxygenases). Special attention was paid to biofiltration - a method for improving the efficiency of treatment of BTEX released from landfills.
\end{abstract}

Keywords: landfilling, biogas, BTEX degradation, biofiltration, ortho-cleavage pathway, meta-cleavage pathway

\section{Introduction}

European Union policy pays great attention to sustainable development ie balancing economic development with quality of environment and quality of life in such a way that intra- and intergenerational justice should be assured. Most resources will be exhausted in the foreseeable future and emissions of greenhouse gases accelerate climate change. In according to Lindzen [1] climate change would not be so catastrophic. Nevertheless careful, more balanced management future development of our civilisation is of great importance [2-6]. Among these problems, greenhouse gas emissions have attracted most interest $[1,7,8]$. One major source of greenhouse gas emissions, particularly of methane, is landfill gas.

Landfilling is the most widely adopted practice for municipal solid waste disposal because it is the most economical waste management strategy currently available. Approximately $75 \%$ of municipal waste is composed of biodegradable organic materials. Different types of materials decompose at different rates. Food waste is hydrolyzed at the fastest rate among all substrates. Paper, cardboard, wood, textiles are slowly degraded while

\footnotetext{
${ }^{1}$ Faculty of Environmental Engineering, Lublin University of Technology, ul. Nadbystrzycka 40B, 20-618 Lublin, Poland, phone: +48 815384408

${ }^{*}$ Corresponding author: e.staszewska@wis.pol.lublin.pl
} 
plastic and rubber are non-degradable $[9,10]$. In the landfills, gaseous products are formed which are harmful to the environment. The most burdensome of these is methane, which content ranges from 48 to $65 \%$ (vol/vol) [11]. Landfills are estimated to contribute $11 \div 32 \mathrm{Tg} \mathrm{CH}_{4} /$ year into the atmosphere $[12,13]$. In situations where the $\mathrm{CH}_{4}$ concentration is lower than $30 \%$ an economical and ecologically applicable way to remove it is via biological oxidation using methanotrophic bacteria [12, 14]. A simplified scheme for the reaction by which methanotrophs oxidise $\mathrm{CH}_{4}$ is as follows $[15,16]$ :

$$
\mathrm{CH}_{4}+2 \mathrm{O}_{2} \rightarrow \mathrm{CO}_{2}+2 \mathrm{H}_{2} \mathrm{O}
$$

Besides methane (Table 1), landfill gas also contains other harmful substances such as non-methane organic compounds detrimental to human health and psychological comfort. According to the EPA report [17] 39\% of Non-methane Organic Compounds (NMOC) produced in landfills are VOCs. In the group of VOCs emitted from landfills most common are: benzene, toluene, ethylbenzene and xylenes (o-, $m-, p$-xylene) (BTEX). It has long been known that exposure to BTEX can lead to numerous health problems including cancer, nervous irritation or damage to the central nervous system [13].

The composition of gases released from landfills [18-20]

\begin{tabular}{|c|c|c|c|}
\hline \multicolumn{4}{|c|}{ The main components of gases emitted from landfills } \\
\hline Compound & Percent by volume & Compound & Percent by volume \\
\hline Methane & $45 \div 60$ & NMOCs & $0.01 \div 0.6$ \\
\hline Carbon dioxide & $40 \div 60$ & (nonmethane organic & \\
\hline Nitrogen & $2 \div 5$ & compounds) & \\
\hline Oxygen & $0.1 \div 1$ & Sulfides & $0 \div 1$ \\
\hline Ammonia & $0.1 \div 1$ & Hydrogen & $0 \div 0.2$ \\
\hline \multicolumn{4}{|c|}{ Trace constituents of the gases emitted from landfills } \\
\hline Compound & $\begin{array}{c}\text { Concentration range } \\
{\left[\mathrm{mg} / \mathrm{m}^{3}\right]}\end{array}$ & Compound & $\begin{array}{c}\text { Concentration range } \\
{\left[\mathrm{mg} / \mathrm{m}^{3}\right]}\end{array}$ \\
\hline \multicolumn{2}{|c|}{ Alkanes } & \multicolumn{2}{|c|}{ Alkenes } \\
\hline Propane & $<0.1 \div 1.0$ & Butadiene & $<0.1 \div 20$ \\
\hline Butane & $<0.1 \div 90$ & Butne & $<0.1 \div 90$ \\
\hline Pentane & $1.8 \div 105$ & Pentadiene & $<0.1 \div 0.4$ \\
\hline \multicolumn{2}{|c|}{ Cycloalkanes } & \multicolumn{2}{|c|}{ Cycloalkenes } \\
\hline Cyclopentane & $<0.2 \div 6.7$ & & \\
\hline Cyclohexane & $<0.5 \div 103$ & Limonene & $2.1 \div 240$ \\
\hline Methylcyclopentane & $<0.1 \div 79$ & Other terpenes & $14.3 \div 311$ \\
\hline \multicolumn{2}{|c|}{ Halogenated compounds } & \multicolumn{2}{|c|}{ Aromatic hydrocarbons } \\
\hline Chloromethane & $<0.1 \div 1$ & & \\
\hline Chlorofluoromethane & $<0.1 \div 10$ & Benzene & $0.4 \div 114$ \\
\hline Dichloromethane & $<0.1 \div 190$ & Styrene & $<0.1 \div 7$ \\
\hline Chloroform & $<0.1 \div 0.8$ & Xylenes & $34 \div 470$ \\
\hline Chlorobenzene & $<0.1 \div 2.1$ & & \\
\hline \multicolumn{2}{|c|}{ Esters } & \multicolumn{2}{|c|}{ Organic compounds containing sulphur } \\
\hline Ethyl acetate & $<0.1 \div 64$ & Carbon sulphide & $<0.1 \div 1$ \\
\hline Methyl butyrate & $<0.1 \div 15$ & Carbon disulphide & $<0.1 \div 2$ \\
\hline Ethyl propionate & $<0.1 \div 136$ & Methyl mercaptan & $<0.1 \div 87$ \\
\hline \multicolumn{2}{|c|}{ Alcohols } & \multicolumn{2}{|c|}{ Ethers } \\
\hline Metanol & $<0.1 \div 210$ & Dimethylether & $0.02 \div 2$ \\
\hline Etanol & $<0.1 \div 810$ & Methylethyloether & $<0.1 \div 2$ \\
\hline Butanol & $<0.1 \div 19$ & Diethylether & $0.1 \div 12$ \\
\hline
\end{tabular}


One promising method for removal of both methane and NMOC is biological oxidation.

Biological oxidation has many advantages, such as the possibility of methane oxidation in a wide range of concentrations and the possibility of oxidation of other harmful pollutants. Researchers [21-29] have described various methods for methane removal from landfills.

\section{Microbial decomposition}

There are a number of microorganisms, which degrade hydrocarbons. Biodegradation of aromatic hydrocarbons with the participation of bacteria consists of five phases:

- absorption of the hydrocarbon molecule to the cell by diffusion or active transport,

- preparation of the substrate to break the ring,

- cleavage of the aromatic ring,

- converting a compound formed after the ring cleavage to amphibiolic intermediates,

- $\quad$ inclusion of intermediates into central metabolic routes.

Most hydrocarbons are biodegradable under both aerobic and anaerobic conditions [30].

\section{Aerobic degradation}

Aerobic biodegradation of aromatic hydrocarbons goes through three key steps: hydroxylation of the aromatic ring, its subsequent cleavage and oxidation to aliphatic compounds to Krebs cycle intermediates and then to $\mathrm{CO}_{2}$ and $\mathrm{H}_{2} \mathrm{O}$ [31]. Key enzymes in the aerobic degradation of aromatic hydrocarbons are oxygenases (di- and monooxygenases). Products of hydroxylation of the ring and its further oxidation are catechol and protocatechuic acid. The reaction is catalyzed by dehydrogenases. These compounds (catechol and protocatechuate) are the substrates of ring-cleavage enzymes. There are two principle routes by which this can occur:

- ortho-cleavage (the intradiol position), or

- meta-cleavage (the estradiol position)

In the ortho-cleavage, the aromatic ring (either in protocatechuate or in catechol) may be opened by cleaving the bond between two neighbouring carbon atoms carrying hydroxyls. If the opening of the aromatic ring involves other bonds taking a meta-position, it is termed meta-cleavage.

Catechol is either oxidized in a reaction catalyzed by catechol-1,2-oxygenase which is an ortho pathway, or is oxidized in a reaction catalyzed by 2,3-dioxygenase, the meta pathway to 2-hydroxymuconic semialdehyde. The products of the final steps of the ortho-cleavage pathway are succinic acid, acetyl-CoA, while further transformation of meta-cleavage leads to acetaldehyde and pyruvate.

Protocatechuate is metabolized by a homologous set of enzymes: protocatechuate 3,4-dioxygenase and protocatechuate 4,5-dioxygenase [30, 32].

Most of bacteria known as good hydrocarbon degraders are chemo-organotrophic species able to use hydrocarbons as a source of carbon and energy. The genetic potential and certain environmental factors such as temperature, $\mathrm{pH}$, nitrogen and phosphorus sources seem to determine the rate and the extent of degradation [34]. 


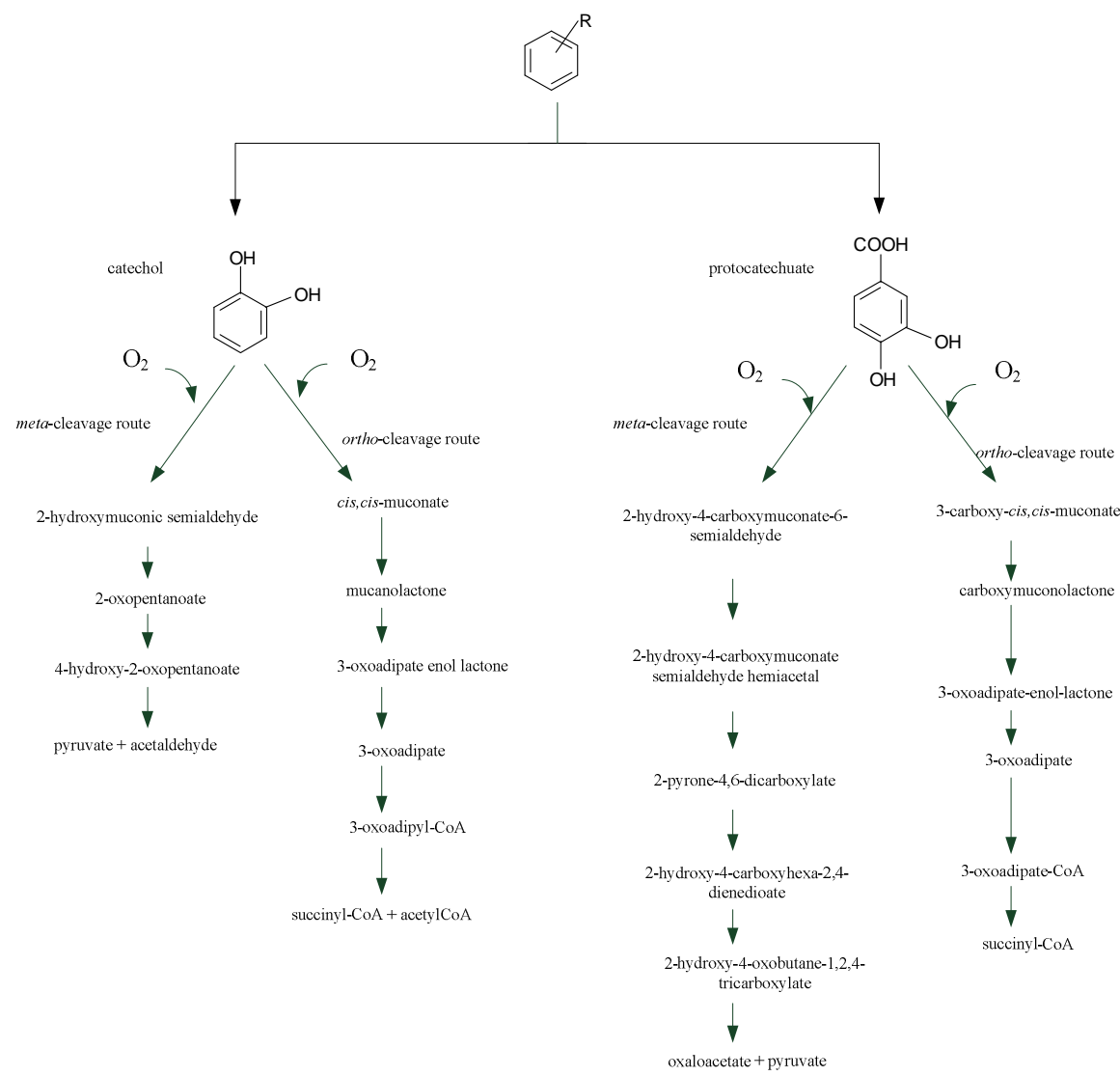

Fig. 1. The biodegradative routes of hydrocarbons $[30,31,33]$

Table 2

BTEX degrading microorganisms - aerobic biodegradation characteristics [35]

\begin{tabular}{|c|c|c|c|}
\hline Substrate & Microorganism & Comments & References \\
\hline \multirow{4}{*}{$\begin{array}{l}\text { BTEX (benzene, } \\
\text { toluene, ethylbenzene, } \\
o-, m \text { - and } p \text {-xylene) }\end{array}$} & Phanerochaete chryosporium & $\begin{array}{c}\text { significant effect of temperature on } \\
\text { degradation rate }\end{array}$ & [36] \\
\hline & $\begin{array}{c}\text { Thermus aquaticus ATCC } \\
25104 \text { and Thermus sp. ATCC } \\
27978\end{array}$ & $\begin{array}{l}\text { BTEX degradation at } 60 \text { and } 70^{\circ} \mathrm{C} \\
(10 \div 40 \%)\end{array}$ & [37] \\
\hline & Rhodococcus rhodochrous & $\begin{array}{l}\text {-xylene enhanced degradation } \\
\text { and ethyl benzene } \\
\text { as a potential inhibitor; } \\
\text { interaction between different } \\
\text { combinations of BTEX } \\
\text { components } \\
\end{array}$ & [38] \\
\hline & $\begin{array}{c}\text { Cladophialophora sp. strain } \\
\text { T1 }\end{array}$ & $\begin{array}{l}\text { toluene and ethyl benzene } \\
\text { as growth substrates, } \\
\text { cometabolism of } \\
o \text { - and } m \text {-xylene }\end{array}$ & [39] \\
\hline
\end{tabular}




\begin{tabular}{|c|c|c|c|}
\hline Substrate & Microorganism & Comments & References \\
\hline \multirow{3}{*}{$\begin{array}{c}\text { benzene, toluene, } \\
p \text {-xylene }\end{array}$} & $\begin{array}{c}\text { Pseudomonas sp. strain } \\
\text { CFS-215; Arthrobacter sp. } \\
\text { strain HCB }\end{array}$ & $\begin{array}{l}\text { benzene dependent degradation of } \\
\text { toluene and } p \text {-xylene; enhanced } \\
\text { degradation of benzene and } \\
p \text {-xylene in the presence of toluene }\end{array}$ & [40] \\
\hline & $\begin{array}{l}\text { Pseudomonas sp. } \mathrm{B} 1 \\
\text { Pseudomonas } \mathrm{sp} . \mathrm{X} 1\end{array}$ & $\begin{array}{l}\text { cometabolic removal of } p \text {-xylene } \\
\text { and benzene-inhibition kinetics }\end{array}$ & [41] \\
\hline & Pseudomonas strain PP01 & cometabolic removal of $p$-xylene & [42] \\
\hline benzene, toluene & Pseudomonas sp. D8 & $\begin{array}{c}\text { degradation of benzene and toluene } \\
\text { in } 30^{\circ} \mathrm{C} \text { and } \mathrm{pH}=7 \text {, effect of } \\
\text { nitrate, sulfate, and phosphate on } \\
\text { degradation }\end{array}$ & {$[43]$} \\
\hline benzene, toluene & Trametes versicolor & $\begin{array}{l}\text { single substrate biodegradation } \\
\text { characteristics }\end{array}$ & {$[44]$} \\
\hline toluene & $\begin{array}{l}\text { Paecilomyces variotii and } \\
\text { Exophiala oligosperma }\end{array}$ & $\begin{array}{c}\text { effect of temperature and } \mathrm{pH} \text { on the } \\
\text { degradation }\end{array}$ & {$[45]$} \\
\hline
\end{tabular}

\section{Anaerobic biodegradation}

During the past two decades anaerobic biodegradation of aromatic pollutants has also been a subject of extensive research. Most microorganisms are not capable of complete degradation of mononuclear aromatic compounds, but they catalyze the anaerobic biotransformation of independent reactions of these compounds. During these changes, the aromatic ring does not undergo fission, and only ring substituents are converted. Degradation of mononuclear aromatic compounds under anaerobic conditions takes place by benzoyl-CoA, which is converted into acetyl-CoA. Since aromatics are more reduced than the products formed, microorganisms capable of degrading these compounds must be able to dispose of the reducing equivalents generated. Degradation of aromatic hydrocarbons has been reported for denitrifying, iron- or sulphate-reducing bacteria as well as photosynthetic and fermenting bacteria [46].

Anaerobic degradation of hydrocarbons is a two-phase process. In the first stage, the aromatic substrates are converted to one of a few central intermediates (usually benzoyl-CoA), which are suitable for reductive dearomatising. In the second phase, degradation of aromatics is initiated by the reduction of these intermediates to acyclic compounds, which are then further degraded to acetyl-CoA and $\mathrm{CO}_{2}[46,47]$.

\section{Method used for landfill gas removal}

Currently used methods for removal of mainly methane from landfills are bio-covers, bio-windows, biofilters, temporary and daily-covers. The most popular are biofilters and biocovers. IPCC recommends biofilters and biocovers as reference methods for mitigation of greenhouse gas emission from landfills. The devices should be commercialized by 2030 $[28,56,57]$. Taking into account that the volatile organic compounds, including BTEX are also oxidized in the aerobic microbial processes, it seemed appropriate to use previously developed methods for removal of methane and these compounds.

As previously mentioned, the most effective methods for removal of methane from landfill gas are biofilters and biocovers. Although the literature on the removal of BTEX from landfills using biocovers is very limited there is much research on BTEX removal by biofiltration (Table 3). 
BTEX degrading microorganisms - anaerobic biodegradation characteristics [35]

\begin{tabular}{|c|c|c|c|}
\hline Substrate & Microorganism & Comments & References \\
\hline \multirow{2}{*}{ benzene } & Geobacter spp. & oxidize benzene in $\mathrm{Fe}(\mathrm{II})$-reducing conditions & \multirow{2}{*}[48,49]{} \\
\hline & Desulfobacterium spp. & benzene mineralization into carbon dioxide in 5 days & \\
\hline \multirow{3}{*}{ toluene } & G. metallireducens & first pure culture for toluene oxidation & \multirow{3}{*}[50,51]{} \\
\hline & Azoarcus spp. & \multirow{2}{*}{ oxidize toluene in nitrate-reducing conditions } & \\
\hline & Thauera spp. & & \\
\hline ethyl benzene & Thauera related & denitrifying bacteria completely mineralize methylbenzene & {$[52,53]$} \\
\hline xylene & D. acetonicum related & mineralizes $o$ - and $m$-xylene & [53-55] \\
\hline
\end{tabular}

\section{Biofiltration}

Biofiltration is an effective and inexpensive technology for the treatment of volatile, toxic air pollutants emitted from landfills. Due to its low investment and operating costs, high efficiency (> 99\%), safe operating conditions and low energy consumption, biofiltration is one of the most effective methods for the removal of gases emitted from landfills. It generates no undesirable by-products and converts many organic and inorganic compounds into harmless oxidation products [58-60].

During biofiltration, landfill gases percolate through the biofilter filled with porous material and are biologically degraded by microorganisms which are immobilisied on packing materials. Acclimation of microorganisms to the newly introduced volatile gases takes between one and two weeks before biodegradation occurs. The packing material within the biofilter (which serves as a habitat and a supplier of nutrients and water) can be composed of biomaterials such as compost, peat, wood bark to more amorphous materials such as charcoal, sand, volcanic ash, porous clay and polystyrene mixture [61, 62]. The selection of suitable materials is one of the key issues in constructing biofilters. First, they should have a high surface area since they must provide sufficient porosity for gas exchange. An appropriate surface area also creates habitats for a large number of microorganisms $[63,64]$. When using natural materials, a significant advantage is the wide diversity of microorganisms that inhabit them - in the immediate proximity to the bacteria there are also a number of fungi and actinomycetes active in the degradation of hazardous substances.

Table 4

Maximum elimination capacity and removal efficiency of BTEX [65]

\begin{tabular}{|c|c|c|c|c|}
\hline Contaminants & Biofilter medium & $\begin{array}{c}\text { Maximum elimination } \\
\text { capacity }\left[\mathbf{g} / \mathbf{m}^{\mathbf{3} / \mathbf{h}]}\right.\end{array}$ & $\begin{array}{c}\text { Average removal } \\
\text { efficiency [\%] }\end{array}$ & References \\
\hline BTX & compost/perlite & $50 \div 60$ & not available & {$[66]$} \\
\hline BTX & compost & not available & $83 \div 97$ & {$[67]$} \\
\hline BTX & compost & 108 & not available & {$[68]$} \\
\hline BTEX & compost & not available & $>90$ & {$[69]$} \\
\hline BTEX & compost & not available & $>80$ & {$[70]$} \\
\hline BTEX & compost & 5.3 & $85 \%$ & {$[65]$} \\
\hline BTEX & compost/active carbon & not available & $90 \%$ & {$[71]$} \\
\hline
\end{tabular}

\section{Conclusions}

Microbial decomposition is the best method to degrade greenhouse gases emitted from landfills. The compounds removed are used by microorganisms for growth and as an energy 
source. The use of a microbial biofilter is reliable, highly efficient and easy to operate and maintain.

\section{References}

[1] Lindzen RS. Global warming: The origin and nature of the alleged scientific consensus. Problems of Sustainable Development. 2010;5:13-28.

[2] Sarkis J. Convincing industry that is value in environmentally supply chains. Problems of Sustainable Development. 2009;2:101-105.

[3] Venkatesh G. Triple bottom line approach to individual and global sustainability. Problems of Sustainable Development. 2010;5:29-37.

[4] Hueting R. Environmentally Sustainable National Income and Other Ways to Improve Information about Growth. Problems of Sustainable Development. 2011;6:31-46.

[5] Hoedl E. Europe 2020 Strategy and European Recovery. Problems of Sustainable Development. 2011;6:11-18.

[6] Udo V, Pawłowski A. Human Progress Towards Equitable Sustainable Development - part II: Empirical Exploration. Problems of Sustainable Development. 2011;6:33-62.

[7] Dołęgowska S. Biofuels - a step towards sustainable development. Problems of Sustainable Development. 2009;4:117-121.

[8] Golomb D. Emission reduction of greenhouse gases: emission quotas or mandated control technologies. Problems of Sustainable Development. 2008;3:23-25.

[9] Lewicki R. Monitoring gazu wysypiskowego. Łódź: OBREM; 1991.

[10] Pawłowska M. Możliwość zmniejszenia emisji metanu z wysypisk na drodze jego biochemicznego utleniania w rekultywacyjnym nadkładzie glebowym - badania modelowe. Lublin: Wydawnictwo Politechniki Lubelskiej; 1999.

[11] Czerwiński J, Pawłowska M. Emissions of trace compounds from selected municipal landfills in Poland. In: Pawłowski L, Dudzińska M, Pawłowski A, editors. Environmental Engineering III. London: Taylor \& Francis Group; 2010.

[12] Le Mer J, Roger P. Production, oxidation, emission and consumption of methane by soils: A review. Eur J Soil Biol. 2011;37:25-50. DOI: 10.1016/S1164-5563(01)01067-6.

[13] Reichenauer TG, Watzinger A, Riesing J, Gerzabek MH. Impact of different plants on the gas profile of a landfill cover. Waste Manage. 2011;31:843-853.

[14] Glatzel S, Stahr K. The trace gas budget of differently managed grassland using the Hohenheim chamber. In: Proceedings of the 16th World Congress of Soil Science. Montpellier/France; 1998.

[15] Semrau JD, Chistoserdov A, Lebron J, Costello A, Davagnino J, Kenna E, Holmes AJ, Finch R, Murrell JC, Lidstrom ME. Particulate methane monooxygenase genes in methanotrophs. J. Bacteriol. 1995; 177:3071-3079.

[16] Stępniewski W, Pawłowska M. Preliminary short-term test of methane oxidation capacity in porous materials - evaluation of reliability. In: Cygas D, Froehner KD, editors. Environmental Engineering. The 7th International Conference, vol. I Environmental Protection; Vilnus: 2008.

[17] EPA 1997 Compilation of Air Pollutant Emissions Factors Volume 1: Stationary Point and Area Sources, Document No. AP-42, Fifth Edition with Supplements, Section 2.4 Municipal Solid Waste Landfills. Washington, DC: U.S. Environmental Protection Agency (US EPA).

[18] EPA 1995 U.S. Environmental Protection Agency. Compilation of Air Pollutant Emissions Factors, AP-42, Fifth Addition, Volume 1: Stationary Point and Area Sources. January 1995. http://www.epa.gov/ttn/chief/ap42/ch02/ Section 2.4 - Municipal Solid waste Landfills.

[19] Tchobanoglous G, Theisen H, Vigil S. Integrated Solid Waste Management, Engineering Principles and Management Issues. New York: McGraw-Hill; 1993.

[20] Williams PT. Waste Treatment and Disposal. Chichester, UK: John Wiley\&Sons, Ltd; 2005.

[21] Chanton J, Liptay K. Seasonal variation in methane oxidation in a landfill cover soil as determined by an in situ stable isotope technique. Global Biogeochem Cycles. 2000;14:51-60. DOI: 10.1029/1999GB900087.

[22] Gebert J, Gröngröft A, Miehlich G. Kinetics of microbial landfill methane oxidation in biofilters. Waste Manage. 2003;23:609-619. DOI: 10.1016/S0956-053X(03)00105-3.

[23] Hilger H, Humer M. Biotic landfill cover treatments for mitigating methane emissions. Environ Monit Assess. 2003;84:71-84. DOI: 10.1023/A:1022878830252. 
[24] Huber-Humer M, Gebert J, Hilger H. Biotic systems to mitigate landfill methane emissions. Waste Manage Res. 2008;26:33-46. DOI: 10.1177/0734242X07087977.

[25] Jugnia LB, Cabral AR, Greer CW. Biotic methane oxidation within an instrumented experimental landfill cover. Ecol. Eng. 2008;33:102-109. DOI: 10.1016/j.ecoleng.2008.02.003.

[26] Perdikea K, Mehrotra AK, Hettiaratchi JPA. Study of thin biocovers (TBC) for oxidizing uncaptured methane emissions in bioreactor landfills. Waste Manage. 2008;28:1364-1374. DOI: 10.1016/j.wasman.2007.06.017.

[27] Scheutz C. Attenuation of methane and trace organics in landfill soil covers [Ph.D Thesis]. Lyngby: Technical University of Denmark; 2002.

[28] Stępniewski W, Pawłowska M. A Possibility to Reduce Methane Emission from Landfills by Its Oxidation in the Soil Cover. Chemistry from the Protection of the Environment 2. Environmental Science Research, Vol. 51. New York: Plenum Press; 1996.

[29] Pawłowska M. Efficiency of microbial oxidation of methane in biofilter. In: Pawłowski L, Dudzińska MR, Pawłowski A, editors. Environmental Engineering, Boca Raton: CRC-Press Taylor\&Francis Group; 2010.

[30] Kwapisz E. Pathways of aerobic petroleum oil hydrocarbons biodegradation, Biotechnologia. 2006;2:166-188.

[31] Greń I, Guzik U, Wojcieszyńska D, Łabużek S. Molecular basis for the degradation of aromatic xenobiotic compounds. Biotechnologia. 2008;2:58-67.

[32] Schlegel HG. Mikrobiologia ogólna. Warszawa: Wyd. Nauk. PWN; 2003.

[33] Smith MR. The biodegradation of aromatic hydrocarbons by bacteria. Biodegradation. 1990;1:191-206. DOI: $10.1007 / \mathrm{BF} 00058836$

[34] Fritsche W, Hofrichter M. Aerobic Degradation by Microorganisms. In: Rehm HJ, Reed G, editors. Biotechnology Set, Second Edition. Weinheim, Germany: Wiley-VCH Verlag GmbH; 2008.

[35] Cao B, Nagarajan K, Loh KC. Biodegradation of aromatic compounds: current status and opportunities for biomolecular approaches. Appl Microbiol Biotechnol. 2009;85:207-228. DOI: $10.1007 / \mathrm{s} 00253-009-2192-4$.

[36] Yadav JS, Reddy CA. Degradation of benzene, toluene, ethylbenzene, and xylenes (BTEX) by the lignindegrading basidiomycete Phanerochaete chrysosporium. Appl Environ Microbiol. 1993;59:756-762.

[37] Chen CI, Taylor RT. Thermophilic biodegradation of BTEX by two Thermus species. Biotechnol Bioen. 1995;48:614-624. DOI: 10.1002/bit.260480609.

[38] Deeb RA, Alvarez-Cohen L. Temperature effects and substrate interactions during the aerobic transformation of BTEX mixtures by toluene enriched consortia and Rhodococcus rhodochrous. Biotechnol Bioen. 1999;62:526-536. DOI: 10.1002/(SICI)1097-0290(19990305)62:5<526::AID-BIT4>3.0.CO;2-8.

[39] Prenafeta-Boldu FX, Vervoort J, Grotenhuis JTC, van Groenestijn JW. Substrate interactions during the biodegradation of benzene, toluene, ethylbenzene, and xylene (BTEX) hydrocarbons by the fugus Cladophialophora sp. strain T1. Appl Environ Microbiol. 2002;68:2660-2665.

[40] Alvarez PJ, Vogel TM. Substrate interactions of benzene, toluene, and paraxylene during microbial degradation by pure cultures and mixed culture aquifer slurries. Appl Environ Microbiol. 1991;57:2981-2985.

[41] Chang MK, Voice TC, Criddle CS. Kinetics of competitive inhibition and cometabolism in the biodegradation of benzene, toluene, and p-xylene by two Pseudomonas isolates. Biotechnol Bioen. 1993;41:1057-1065. DOI: 10.1002/bit.260411108.

[42] Oh YS, Sharafdeen Z, Baltizs BC, Bartha R. Interactions between benzene, toluene, and p-xylene (BTX) during their biodegradation. Biotechnol Bioeng. 1994;44:533-538. DOI: 10.1002/bit.260440417.

[43] Chang BV, Wu WB, Yuan SY. Biodegradation of benzene, toluene, and other aromatic compounds by Pseudomonas sp. D8. Chemosphere. 1997;35:2807-2815. DOI: 10.1016/S0045-6535(97)00281-6.

[44] Demir G. Degradation of toluene and benzene by Trametes versicolor. J Environ Biol. 2004;25:19-25.

[45] Estevez E, Veiga MC, Kennes C. Biodegradation of toluene by the new fungal isolates Paecilomyces variotii and Exophiala oligosperma. J Ind Microbiol Biot. 2005;32:33-37. DOI: 10.1007/s10295-004-0203-0.

[46] Guzik U, Wojcieszyńska D, Hupert-Kocurek K. Microbiological degradation of aromatic compounds in anoxic condition. Postępy Mikrobiologii. 2010;49:217-226.

[47] Heider J, Fuchs G. Microbial anaerobic aromatic metabolizm. Anaerobe. 1997;3:1-22.

[48] Coates JD. Chakraborty R. Lack JG, O’Connor SM, Cole KA, Bender KS, Achenbach LA. Anaerobic benzene oxidation coupled to nitrate reduction in pure culture by two sytains of Dechloromonas. Nature. 2001; 411: 1039-1043. 
[49] Rooney-Varga JN, Anderson RT, Fraga JL, Ringelberg D, Lovley DR. Microbial communities associated with anaerobic benzene degradation in petroleum-contaminated aquifer. Appl Environ Microbiol. 1999;65:3056-3063.

[50] Chakraborty R, Coates JD. Anaerobic degradation of monoaromatic hydrocarbons. Appl Microbiol. Biotechnol. 2004;64:437-446. DOI: 10.1007/s00253-003-1526-X.

[51] Lovley DR, Baedecker MJ, Lonergan DJ, Cozzarelli IM, Philips EJP, Siegel DI. Oxidation of aromatic contaminants coupled to microbial iron reduction. Nature. 1998;339:297-300.

[52] Ball HA, Johnson HA, Reinhard M, Spormann AM. Initial reactions in anaerobic ethylbenzene oxidation by a denitrifying bacterium, strain EB1. J. Bacteriol. 1996;178:5755-5761.

[53] Rabus R, Widdel F. Anaerobic degradation of ethylbenzene and other aromatic-hydrocarbons by new denitrifying bacteria. Arch Microbiol. 1995;163:96-103. DOI: 10.1007/BF00381782.

[54] Harms G, Zengler K, Rabus R, Aeckersberg F, Minz D, Rossello-Mora R, Widdel F. Anaerobic oxidation of o-xylene, m-xylene, and homologous alkylbenzenes by new types of sulfate-reducing bacteria. Appl Environ Microbiol. 1999;65:999-1004.

[55] Hess A, Zarda B, Hahn D, Häner A, Stax D, Höhener P, Zeyer J. In situ analysis of denitrifyin toluene- and $\mathrm{m}$-xylene-degrading bacteria in a diesel fuel-contaminated laboratory aquifer column. Appl Environ Microbiol. 1997;63:2136-2141.

[56] IPPC Fourth Assessment Report: Climate Change; 2007.

[57] Jiang H, Chen Y, Jiang P, Zhang C, Smith J, Murrell JC, Xing XH. Methanotrophs: Multifunctional bacteria with promising application in environmental bioengineering. Biochem Eng J. 2010;49:277-288. DOI: 10.1016/j.bej.2010.01.003.

[58] Borin S, Marzorati M, Brusetti L, Zilli M, Cherif H, Abdennaceur H, Converti A, Sorlini C, Daffonchio D. Microbial succession in a compost-packed biofilter treating benzene-contaminated air. Biodegradation. 2006; 17:79-89. DOI: 10.1007/s10532-005-7565-5.

[59] Zdeb M, Pawłowska M. An influence of temperature on microbial removal of hydrogen sulphide from biogas. Roczn Ochr Środow, Koszalin; 2009:1235-1243.

[60] Pawłowska M. Usuwanie metanu z gazu składowiskowego w biofiltrach metanotroficznych. Monografie Komitetu Inżynierii Środowiska PAN; Lublin; 2010.

[61] Mallakin A, Ward OP. Degradation of BTEX compounds in liquid media and in peat biofilters. J Ind Microbiol. 1996;16:309-318. DOI: 10.1007/BF01570040.

[62] Stępniewski W, Pawłowska M. Biofilters and biocovers of landfills - Effect of biophysical factors on their efficency. In: Alamgir M, Hossain QS, Rafizul IM, Mohiuddin KM, Bari QH. editors. Kbulna Proceedings of the National Seminar on Solid Waste Management - WasteSafe, Bangladesz; 2008.

[63] Łebkowska M, Tabernacka A. Biologiczne metody usuwania zanieczyszczeń gazowych metodą biofiltracji. Biotechnologia. 2000;3:141-150.

[64] Pawłowska M, Rożej A, Stępniewski W. Effect of bed properties on methane removal potential in aerated biofilter - model studies. Waste Manage. 2010;56:8-17. DOI: 10.1016/j.wasman.2010.10.005.

[65] Namkoong W, Park JS, VanderGheynst JS. Biofiltration of gasoline vapor by compost media. Environ Pollut. 2003;121:181-187. DOI: 10.1016/S0269-7491(02)00223-3.

[66] Seed LP, Corsi RL. Biofiltration of BTEX Contaminated Streams: Laboratory Studies. In: Proc. of 87th Annual Meeting and Exibition of the AWMA. A\&WMA, Pittsburgh, PA; 1994.

[67] Ergas SJ, Schroeder ED, Chang DPY, Morton RL. Control of volatile organic compound emissions using a compost biofilter. Water Environ Research. 1995;67:816-821. DOI: 10.2175/106143095X131736.

[68] Tahraoui K, Rho D. Biodegradation of BTEX vapors in a compost medium biofilter. Compost Sci Utilization. 1998;6:13-21.

[69] Wright WF, Schroeder ED, Chang DPY, Romstad K. Performance of a pilot-scale compost biofilter treating gasoline vapor. J Environ Eng. 1997:123,547-555. DOI:10.1061/(ASCE)0733-9372(1997)123:6(547).

[70] Thompson D, Sterne L, Bell J, Parker W, Lye A. Pilot scale investigation of sustainable BTEX removal with a compost biofilter. In: Proc. of 89th Annual Meeting and Exhibition. A\&WMA, Nashville; 1996.

[71] Abumaizar RJ, Kocher W, Smith EH. Biofiltration of BTEX contaminated air streams using compost-activated carbon filter media. J Hazard Mater. 1998;60:111-126. DOI:10.1016/S0304-3894(97)00046-0. 


\title{
DEGRADACJA GAZÓW ZE SKŁADOWISK ZE SZCZEGÓLNYM UWZGLĘDNIENIEM BTEX
}

\author{
Wydział Inżynierii Środowiska, Politechnika Lubelska
}

\begin{abstract}
Abstrakt: Składowiska odpadów są najtańszą i najprostszą metodą ich zagospodarowania. Ze względu na uwalnianie z nich znacznych ilości lotnych związków organicznych (VOC) składowiska stanowią zagrożenie dla czystości powietrza, wód gruntowych oraz gleb. W grupie VOC uwalnianych ze składowisk odpadów najbardziej powszechne i jednocześnie bardzo toksyczne są BTEX (benzen, toluen, etylobenzen, ksyleny). Z tego też względu ważne jest poszukiwanie efektywnych metod eliminacji tych związków ze składowisk odpadów. W artykule przedstawiono obecny stan wiedzy odnoszący się do degradacji BTEX przez mikroorganizmy oraz opis metod stosowanych do usuwania BTEX ze składowisk odpadów ze szczególnym uwzględnieniem procesu biofiltracji.
\end{abstract}

Słowa kluczowe: składowiska odpadów, biogaz, degradacja BTEX, biofiltracja 